\title{
The Importance of Leadership Education in University: Self-Leadership Example
}

\author{
Elif Bozyigit ${ }^{1}$ \\ ${ }^{1}$ Faculty of Sport Sciences, Pamukkale University, Denizli, Turkey \\ Correspondence: Elif Bozyigit, Faculty of Sport Sciences, Pamukkale University, Denizli, Turkey.
}

Received: November 16, 2018

Accepted: December 21, $2018 \quad$ Online Published: March 10, 2019

doi:10.5539/ies.v12n4p1

URL: https://doi.org/10.5539/ies.v12n4p1

\begin{abstract}
Self-leadership is a form of leadership that has emerged in the last quarter of a century. The purpose of this study is to determine whether there is a difference in self-leadership strategies between students who choose leadership course and do not choose. The sample of this research consisted of 144 sports management students in 2018; 35 female $(24.3 \%)$ and 109 male $(75.7 \%)$. The average age of students is $22.38(\mathrm{sd}=2.88)$. While 30 students $(20.8 \%)$ stated that they chose leadership course, 114 students $(79.2 \%)$ stated that they did not choose leadership course. In this study, the Turkish version of Abbreviated Self-Leadership Questionnaire (ASLQ) was used as a data collection tool, but original ASLQ was developed by Houghton et al. (2012). The Turkish version of the scale was adopted by Şahin (2015). As a result of the reliability analysis, the Cronbach's alpha value was found to be .74 . There was a significant difference between ASLQ total scores of students who choose the leadership course and do not choose (yes/no). There was a significant difference between students who choose the leadership course and do not choose (yes/no) and the subscale scores; behavior awareness and volition, constructive cognition, and task motivation. According to the results obtained through the analysis, hypothesis 1 and 2 were accepted.
\end{abstract}

Keywords: leadership course, leadership training, self-leadership, sport management student

\section{Introduction}

Since its emergence or recognition, leadership has been a curious concept for researchers to make a definition. In most of the definitions related to leadership, there are statements such as leading a group, mobilizing, motivating the employees to make their business more efficient, gathering a group of people for a specific purpose, perceiving the problem and showing the solution options to the members (Doğan, 2007; Eren, 2000; Sungur, 1997). When the leadership theories are examined, it is seen that it develops in four basic stages. In general, leadership theories are classified as follows: Trait Theory in the 1930s, Behavioral Theories in the 1940s, Contingency Theories in the 1960s, Modern/Contemporary approaches to Leadership in the 1970s, and Neo-Charismatic Theories in the 1990s.

When the Modern Leadership Theories are examined, it is seen that leadership styles such as cultural leadership, visionary leadership, teaching leadership, ethics leadership, super leadership and self-leadership emerged. Stewart et al. (2011) stated that some studies have focused on the concept of self-leadership in the last 30 years. Bozyigit (2018) also stated that research on leadership will continue.

Self-leadership is a form of leadership that has emerged in the last quarter of a century. It refers to direct self-motivation tasks of individuals and their self-directing (Manz, 1986). Self-leadership can be expressed as leading or a process of influence (Neck \& Manz, 1992). Neck and Manz (1996) stated that self-leadership focuses on the individual's thoughts and self-behaviors, and Godwin et al. (1999) also indicated that it focused on cognition and behavior. This is in the form of mental imagery, self-talk, beliefs, thought patterns, and assumptions (Manz, 1986; Manz \& Sims, 1980; Neck \& Houghton, 2006). According to Houghton and Neck (2002), self-leadership is a process through which people influence themselves to achieve self-motivation and self-direction necessary to behave and perform in desirable ways. At the same time, there are some practical strategies and specific self-leadership skills areas, and these include self-goal-setting, rehearsal, self-observation, self-job redesign, self-reward, and self-management of internal dialogues and mental imagery (Pearce \& Manz, 2005).

Based on the theoretical bases in social cognitive theory and intrinsic motivation theory, self-leadership consists of three different strategies (Anderson \& Prussia, 1997; Houghton \& Neck, 2002; Kazan, 1999; Manz \& Neck, 2004; 
Manz \& Sims, 2001; Neck \& Houghton, 2006). These strategies are behavior-oriented strategies, natural reward strategies and constructive thinking pattern strategies (Manz, 1986, 1992), when these strategies are briefly explained.

Behavior-focused strategies; Politis (2006) stated that Manz developed a theory, which goes beyond the Bandura's study of self-control. According to this theory, behavior-focused strategies provide specific approaches to identify ineffective behaviors and to replace them with more effective ones (Houghton et al., 2012). These strategies include self-reward, self-cueing, self-observation, self-punishment, self-goal setting, self-correcting feedback and practice and are based on these processes (Doğan \& Şahin, 2008; Manz, 1992; Manz \& Neck, 2004; Manz \& Sims, 1980; Neck \& Houghton, 2006; Tabak, Sığrı, \& Türköz, 2013). Houghton and Neck (2002) stated that these strategies were designed to encourage positive, desirable behaviors that lead to successful outcomes, while suppressing negative, undesirable behaviors that lead to unsuccessful outcomes. In another study, Neck et al. (2003) expressed that the construct of the "organizational environment" constituted an important element in their comprehensive model.

Natural reward strategies focus on the enjoyable aspects of a task or an activity (Anderson \& Prussia, 1997; Manz \& Neck, 2004; Manz \& Sims, 2001; Neck \& Houghton, 2006). Natural reward strategies can be expressed as situations in which the fun aspects of the task or activity are motivated or rewarded by the individual. First of all, the task or activity should be provided with a pleasurable qualification, so a natural reward should be provided. Then, the individual should move away from the negative aspects of the task and focus on rewarding aspects (Manz \& Neck, 2004; Manz \& Sims, 2001; Neck \& Houghton, 2006). In this way, the individual who focuses on the pleasant aspects of the task exhibits better performance and increases their performance (Houghton \& Neck, 2002). In a study conducted by Güllü (2018), it was found that employees had a higher than average level of happiness. Employees' positive thinking about this happiness situation can create their own natural reward strategies. These strategies consist of two basic natural reward strategies: building more pleasant features for the task and shaping perceptions for the task (Manz \& Neck, 2004; Manz \& Sims, 2001; Neck \& Houghton, 2006).

Constructive thought pattern strategies can be expressed as the formation of constructive thought patterns and the formation of habits that will affect the performance positively. Neck et al. (2003) stated that Manz (1992) described a thought pattern as "certain ways of think about our experiences" and "habitual ways of thinking". These strategies include the definition and change of non-functional beliefs and assumptions, mental images, and self-talk (Neck \& Houghton, 2006). Positive and effective thought patterns are developed. Negative thoughts are reduced (Manz, 1986; Manz \& Neck, 2004; Manz \& Sims, 2001; Neck \& Houghton, 2006; Neck \& Manz, 1992, 1996). Mental imagery refers to imagining successful performance of task before it is actually completed (Neck et al, 2003). According to Ekmekçi (2017), mental imagination is a very effective mental preparation technique. Imagery means fully imagining and animating in the mind.

More and more companies faced adaptive challenges: changes in societies, markets, and technology around the globe were forcing them to clarify their values, develop new strategies, and learn new ways of operating. And also, the most important task for leaders in the face of such challenges was mobilized people throughout the organization to do adaptive work, and for many senior executives, providing such leadership was difficult (Heifetz \& Laurie, 1997). In the light of these influences, many researchers (Manz, 1986; Manz \& Sims, 1980, 1987, 2001; Markham \& Markham, 1995; Politis, 2003; Robbins, 2003; Stewart \& Manz, 1995) investigated self-leadership strategies and self-management.

Leadership has been a common topic for historians, psychologists, political scientists, and people in practice and organizational behavior experts in different fields (Vohra et al., 2015). In the last century, more than 200 articles were published related to leadership. However, there is little emphasis on whether leadership training is valuable (Avolio, Avey, \& Quisenberry, 2010). Nowadays, leadership training is becoming increasingly important. It can be said that leadership training is very important in developing the above mentioned strategies. There are various institutions and organizations providing leadership training. Leadership training is offered online and in schools as formal education. Kirchner and Akdere (2014) also stated that worldwide organizations benefit from leadership development programs. Ardichvili and Manderscheid (2008) indicate that in leadership development programs, maximum percentage of funds allocated to education and development departments usually go to leadership development.

Social, economic, political, and technological changes and developments in the global world affect the need for more effective leaders in the business sector (Amagoh, 2009). Leadership and need for leader is often discussed in modern administrations. Managers are expected to have leadership characteristics. Therefore, leadership training should be given to every student who receives management training. 
Most leadership training programs are not designed for habit formation. These programs are event-based trainings, meaning that the training takes place over a day or two (Levy, 2018). There are many training programs organized specifically for leadership development (Boyce, Jackson, \& Neal, 2010). An ideal program to train leaders should include: create a knowledge base, gain the desired skills, and help them understand their own beliefs and values and their impact on others (Stech, 2008). Leadership coaching is also one of these programs, and it focuses specifically on the student (Ely et al., 2010). Leadership training should aim to bring new skills to leaders. This can be thanks to long-term training.

There are training programs for management education at universities in Turkey. For example; Department of Business Administration, Department of Labor Economics and Industrial Relations, Political science and public administration etc. The Sports Management Department is also one of them. The Department of Sport Management is one of the departments that are given management education for sports.

In the research, when the educational programs of the sports management students are examined, it is determined that there are many different courses related to management. However, courses related to leadership are in elective courses and the course is 3 hours per week, and they can be selected once during the 4-year training period. According to Information Package and Course Catalogue of Pamukkale University (PAU-IPCC, 2018), these courses are as follows:

The courses in this department are divided into elective and compulsory courses. The compulsory courses on management are management science, public administration, general business, sport management, recreation management, ethics in sport and management, organization management, special topics in sports management. Elective courses related to management include club structure management and problems, international sports management, contemporary developments in management, crisis management, risk management, total quality management, strategic planning in management, sports officiating and competition management. Elective courses related to leadership; leadership and sports, group dynamics and leadership, and educational leadership.

In the light of all this information, in this research, the importance of leadership training has been emphasized. For that reason, the aim of this study is to determine whether there is a difference in self-leadership strategies between students who choose leadership course and do not choose. Two hypotheses were created for this purpose:

Hypothesis 1. There is a significant difference between ASLQ total scores of students who choose the leadership course and do not choose.

Hypothesis 2. There is a significant difference between the subscale scores of students who choose the leadership course and do not choose.

\section{Method}

\subsection{Participants}

The sample of this research consisted of 144 sports management students in 2018; 35 female (24.3\%) and 109 male (75.7\%). The average age of students is $22.38(\mathrm{sd}=2.88)$. While 30 students $(20.8 \%)$ stated that they chose group dynamics and leadership course, 114 students $(79.2 \%)$ stated that they did not choose group dynamics and leadership course.

\subsection{Procedure}

All data were collected during the spring semester of 2018. Participants were informed about the research. The questionnaire was administrated by the researcher to participants during the lessons. Students were encouraged to ask questions if they had difficulty understanding instructions or items in the questionnaires. And, also, it was stated that the research results can be shared with them. The questionnaire was completed on average 6 minutes.

\subsection{Measures}

In this study, the Turkish version of Abbreviated Self-Leadership Questionnaire (ASLQ) was used as a data collection tool, but original ASLQ was developed by Houghton et al. (2012). The Turkish version of the scale was adopted by Şahin (2015). His study the results indicated that the one-factor model provided the best fit compared to the three-factor model of the ASLQ. And also, he found that total score on the ASLQ correlated strongly with the RSLQ (Houghton and Neck, 2002). Cronbach's alpha value of the Turkish version of the ASLQ was found to be .75 by Şahin (2015). The questionnaire has included nine items. It is a 5-point Likert-type scale ranging from 1 (strongly disagree) to 5 (strongly agree). All its items are positive. There are three subscales in the questionnaire. 1) behavior awareness and volition, 2) task motivation, and 3) constructive cognition. 


\subsection{Analyses}

In this study, SPSS package program was used for statistical analysis. In the analysis of the data, Z-test was used to determine whether the scores are normally distributed. It was determined that the resulting analysis data were normally distributed. The $\mathrm{t}$ test was used to determine the difference between the two groups (Büyüköztürk, 2018). The significance level for hypothesis was determined to be .05. As a result of the reliability analysis, the Cronbach's alpha value was found to be .74 .

\section{Results}

The results of the hypotheses to be tested in the current study were given in the tables below.

Hypothesis 1. There is a significant difference between ASLQ total scores of students who choose the leadership course and do not choose.

Table 1. T test results according to ASLQ total score

\begin{tabular}{|c|c|c|c|c|c|c|c|c|}
\hline \multirow{2}{*}{ ASLQ } & \multirow{2}{*}{ Choosing course } & \multirow{2}{*}{$\mathrm{n}$} & \multirow{2}{*}{$\overline{\mathrm{X}}$} & \multirow{2}{*}{ sd } & \multirow{2}{*}{ sd mean } & \multicolumn{3}{|c|}{ t test } \\
\hline & & & & & & $\mathrm{t}$ & $\mathrm{sd}$ & $\mathrm{p}$ \\
\hline \multirow{3}{*}{ Total score } & Yes & 30 & 39.43 & 3.953 & .722 & 3.973 & 142 & $.000 *$ \\
\hline & No & 114 & 35.62 & 4.841 & .453 & & & \\
\hline & Total & 144 & & & & & & \\
\hline
\end{tabular}

$\mathrm{p}<.05$.

There was a significant difference between ASLQ total scores $\left[\mathrm{t}_{(142)}=3.973, \mathrm{p}<.05\right]$ of students who choose the leadership course and do not choose (yes/no).

Hypothesis 2. There is a significant difference between the subscale scores of students who choose the leadership course and do not choose.

Table 2. T test results according to the subscale scores

\begin{tabular}{|c|c|c|c|c|c|c|c|c|}
\hline \multirow{2}{*}{ ASLQ } & \multirow{2}{*}{ Choosing course } & \multirow{2}{*}{$\mathrm{n}$} & \multirow{2}{*}{$\overline{\mathrm{X}}$} & \multirow{2}{*}{$\mathrm{sd}$} & \multirow{2}{*}{ sd mean } & \multicolumn{3}{|c|}{ t test } \\
\hline & & & & & & $\mathrm{t}$ & $\mathrm{sd}$ & $\mathrm{p}$ \\
\hline \multirow{2}{*}{$\begin{array}{c}\text { Behavior awareness and } \\
\text { volition }\end{array}$} & Yes & 30 & 13.33 & 1.625 & 1.626 & 2.930 & 142 & $.004^{*}$ \\
\hline & No & 114 & 12.20 & 1.942 & 1.942 & & & \\
\hline \multirow{2}{*}{ Task motivation } & Yes & 30 & 12.90 & 1.787 & 1.788 & 2.797 & 142 & $.002 *$ \\
\hline & No & 114 & 11.75 & 2.046 & 2.046 & & & \\
\hline \multirow{3}{*}{ Constructive cognition } & Yes & 30 & 13.20 & 1.374 & 1.375 & 3.966 & 142 & $.000 *$ \\
\hline & No & 114 & 11.67 & 1.994 & 1.994 & & & \\
\hline & Total & 144 & & & & & & \\
\hline
\end{tabular}

There was a significant difference between students who choose the leadership course and do not choose (yes/no) and the subscale scores; behavior awareness and volition $\left[\mathrm{t}_{(142)}=2.930, \mathrm{p}<.05\right]$, task motivation $\left[\mathrm{t}_{(142)}=2.797\right.$, $\mathrm{p}<.05]$, constructive cognition $\left[\mathrm{t}_{(142)}=3.966, \mathrm{p}<.05\right]$.

\section{Discussion}

In this study, self-leadership levels of Sports Management students who choose and do not choose leadership courses were examined. The results of the research revealed that the students who chose leadership courses were above the average score in terms of leadership strategies. And, it was observed that the students who chose the leadership course had higher leadership scores than the students who did not (Table 1). Statistically, a significant difference was found between the total scores of the students who chose the leadership course and the scores of the students who did not. According to this result obtained, it can be interpreted that it is important to take leadership training. And also, a significant difference was found between the subscale scores of the students who chose the leadership course and the scores of the students who did not (Table 2). This finding shows that the students who choose the leadership course have higher scores in terms of behavior awareness and volition, constructive cognition, and task motivation. Extejt and Smith (2009), in a study on leadership development through participation in sports teams, found that the leadership skills of sports team participants differed from non-participants. Tekin and Zorba (2001) also stated that in sport and recreational organizations, sport 
administrators were responsible for determining the goals and empowering subordinates to achieve the results, and emphasize the importance of the leadership abilities of the managers in the success of the organization. As a result of a study conducted by Külekçi (2016), it was found that education was effective in the development of students' leadership skills in leading a group. In a similar study conducted by Marcketti et al. (2011) in relation to development of student leadership in the event management course, it was found that the students' mean scores increased significantly for all the application areas between before and after. Özçelik-Herdem (2019) suggests in a study that efforts should be made to start developing self-leadership skills of the students.

\section{Conclusion}

Leaders in sports institutions know the use of all kinds of resources, and not only control but also pioneer of development and innovation (Imbroda-Ortiz et al., 2015). According to some researchers (Riggio, 2008; Virakul \& McLean, 2012), the success of the institution or corporation depends on the ability of the organization to develop the leadership capability of its personnel. Development takes place through education. Therefore, it can be said that the high level of leadership strategies of the students can be effective in the success of the organizations they will work in the future. It is thought that students can be a successful manager-leader by combining what they have learned in leadership trainings with the practices in the workplace.

In this study, two hypotheses were established regarding the self-leadership levels of the students who chose and did not choose the leadership course. According to the results obtained through the analysis, hypothesis 1 and 2 were accepted. In the literature, although there was a lot of research on leadership and self-leadership (Al-Jamal \& Ghamrawi, 2015; Arlı \& Avc1, 2017; Ay et al., 2015; Furtner et al., 2010; Godwin et al., 1999; Ho \& Nesbit, 2013; Kalyar, 2011; Semerci, 2010; Sesen et al., 2017; Türköz et al., 2013; Zyl, 2012), there could not come across research on the students who chose leadership education.

\section{References}

Al-Jammal, K., \& Ghamrawi, N. (2015). Leading the self: Self-leadership skills of Lebanese private school principals. International Journal of Social Science and Economics Invention, 1(2), 1-20.

Amagoh, F. (2009). Leadership development and leadership effectiveness. Management Decision, 47(6), 989-999. https://doi.org/10.1108/00251740910966695

Anderson, J. S., \& Prussia, G. E. (1997). The self-leadership questionnaire: Preliminary assessment of construct validity. The Journal of Leadership Studies, 4, 119-143. https://doi.org/10.1177/107179199700400212

Ardichvili, A., \& Manderscheid, S. V. (2008). Emerging practices in leadership development: An introduction. Advances in Developing Human Resources, 10(5), 619-631. https://doi.org/10.1177/1523422308321718

Avolio, B. J., Avey, J. B., \& Quisenberry, D. (2010). Estimating return on leadership development investment. The Leadership Quarterly, 21(4), 633-644. https://doi.org/10.1016/j.leaqua.2010.06.006

Ay, F. A., Karakaya, A., \& Yılmaz, K. (2015). Relationship between self-leadership and critical thinking skills. Procedia-Social and Behavioral Sciences, 207, 29-41. https://doi.org/10.1016/j.sbspro.2015.10.147

Boyce, L. A., Jackson, R. J., \& Neal, L. J. (2010). Building successful leadership coaching relationships: Examining impact matching criteria in a leadership coaching program. The Journal of Management Development, 29(10), 914-931. https://doi.org/10.1108/02621711011084231

Bozyigit, E. (2018). Self-leadership: Volleyball student-players and their competition achievement. European Journal of Physical Education and Sport Science, 4(10), 32-49. https://doi.org/10.5281/zenodo.1400814

Büyüköztürk, Ş. (2018). Sosyal bilimler için veri analizi el kitabi. 24. Baskı, Ankara: Pegem Akademi. https://doi.org/10.14527/9789756802748

Doğan, S. \& Şahin, F. (2008). Bireysel performansı ve verimliliği artIrmada kendi kendine liderlik yaklaşımının önemi. İ̧̧ü̧-Endüstri Illişkileri ve İnsan Kaynakları Dergisi, 10(1), 77-95.

Doğan, S. (2007). Vizyona dayalı liderlik, 2. Baskı, İstanbul: Kare Yayınları.

Ekmekçi, R. (2017). Sporda zihinsel antrenman: Bir adım önde. Detay Yayıncılık.

Ely, K., Boyce, L. A., Nelson, J. K., Zaccaro, S. J., Hernez-Broome, G., \& Whyman, W. (2010). Evaluating leadership coaching: A review and integrated framework. The Leadership Quarterly, 21(4), 585-599. https://doi.org/10.1016/j.leaqua.2010.06.003

Eren, E. (2000). Örgütsel davranış ve yönetim psikolojisi. İstanbul: Beta Yayınları.

Extejt, M. M., \& Smith, J. E. (2009). Leadership development through sports team participant. Journal of 
Leadership Education, 8(2), 224-237. https://doi.org/10.12806/V8/I2/RF7

Furtner, R. M., RauthMann, J. F., \& SachSe, P. (2010). The socioemotionally intelligent self-leader: examining relations between self-leadership and socioemotional intelligence. Social Behavior and Personality, 38(9), 1191-1196. https://doi.org/10.2224/sbp.2010.38.9.1191

Godwin, L. J., Neck, C. P., \& Houghton, J. D. (1999). The impact of thought self-leadership on individual goal performance: A cognitive perspective. The Journal of Management Development, 18(2), 153-169. https://doi.org/10.1108/02621719910257738

Güllü, S. (2018). Spor işletmelerinde çalışan mutluluğu. International Journal of Social Sciences and Education Research, 4(3), 547-559. https://doi.org/10.24289/ijsser.428854

Heifetz, R. A., \& Laurie, D. L. (1997). The work of leadership. Harvard Business Review, 75(1), 124-134.

Ho, J., \& Nesbit, P. L. (2013). Exploring self-leadership across eastern and western cultures. Journal of Service Science and Management, 6, 241-249. https://doi.org/10.4236/jssm.2013.64027

Houghton, D. J. \& Neck, C. P. (2002). The revised self-leadership questionnaire: Testing a hierarchical factor structure for self-leadership. Journal of Managerial Psychology, 17(8), 672-691.

Houghton, D. J., Dawley, D., \& DiLiello, T. C. (2012). Abbreviated self-leadership questionnaire (ASLQ): A more concise measure of self-leadership. International Journal of Leadership Studies, 7(2), 216-232. https://doi.org/10.1108/02683940210450484

Imbroda-Ortiz, J., Castillo-Rodriguez, A., \& Chinchilla-Minguet, J. L. (2015). Sports management, leadership in the organization. Journal of Physical Education and Sports Management, 2(2), 56-65. http://dx.doi.org/10.15640/jpesm.v2n2a5

Kalyar, M. N. (2011). Creativity, self-leadership and individual innovation. The Journal of Commerce, 3(3), 20-28.

Kazan, A. L. (1999). Exploring the concept of self-leadership: Factors impacting self-leadership of Ohio Americorp's Members (Doctoral Dissertation, Ohio: The Ohio State University).

Kirchner, M. J., \& Akdere, M. (2014). Leadership development programs: An integrated review of literature. The Journal of Knowledge Economy \& Knowledge Management, 9(1), 137-146.

Külekçi, E. (2016). An experimental study about developing undergraduate students' socially responsible leadership skills. International Journal of Eurasia Social Sciences, 7(22), 56-80.

Levy, A. (2018). Why leadership training doesn't work. Retrieved from https://www.forbes.com/sites/forbescoachescouncil/2018/02/23/why-leadership-training-doesnt-work/\#3685db1177a4

Manz, C. C. (1986). Self-leadership: Toward an expanded theory of self-influence processes in organizations, Academy of Management Review, 11(3), 585-600. https://doi.org/10.5465/amr.1986.4306232

Manz, C. C. (1992). Mastering Self-leadership: Empowering Yourself for Personal Excellence. Prentice-Hall, Englewood Cliffs, NJ.

Manz, C. C., \& Neck, C. P. (2004). Mastering self-leadership: Empowering yourself for personal excellence (3rd ed.). Upper Saddle River, NJ: Prentice Hall.

Manz, C. C., \& Sims, H. P. (1980). Self-management as a substitute for leadership: A social learning theory perspective. Academy of Management Review, 5(3), 361-367. https://doi.org/10.5465/amr.1980.4288845

Manz, C. C., \& Sims, H. P. (1987). Leading workers to lead themselves, The external leadership of self-managing work teams. Administrative Science Quarterly, 32, 106-129. https://doi.org/10.2307/2392745

Manz, C. C., \& Sims, H. P. (2001). The new superleadership: Leading others to lead themselves. Berrett-Koehler Store.

Marcketti, S. B., Arendt, S. W., \& Shelley, M. C. (2011). Leadership in action: Student leadership development in an event management course. Leadership and Organization Development Journal, 32(2), 170-189. https://doi.org/10.1108/01437731111112999

Markham, S. E., \& Markham, I. S. (1995). Self-management and self-leadership reexamined: a levels-of-analysis perspective. Leadership Quarterly, 6(3), 343-359. https://doi.org/10.1016/1048-9843(95)90013-6

Neck, C. P., \& Houghton, J. D. (2006). Two decades of self-leadership theory and research: Past developments, present trends, and future possibilities. Journal of Managerial Psychology, 21(4), 270-295. 
https://doi.org/10.1108/02683940610663097

Neck, C. P., \& Manz, C. C. (1992). Thought self - leadership: The influence of self - talk and mental imagery on performance. Journal of Organizational Behavior, 13(7), 681-699. https://doi.org/10.1002/job.4030130705

Neck, C. P., \& Manz, C. C. (1996). Thought self-leadership: The impact of mental strategies training on employee cognition, behavior, and affect. Journal of Organizational Behavior, 17(5), 445-467. https://doi.org/10.1002/(SICI)1099-1379(199609)17:5<445::AID-JOB770>3.0.CO;2-N

Neck, C. P., Nouri, H., \& Godwin, J. L. (2003). How self-leadership affects the goal-setting process. Human Resource Management Review, 13, 691-707. https://doi.org/10.1016/j.hrmr.2003.11.009

Özçelik-Herdem, D. (2019). A comparison of self-leadership characteristics of the student of department of fine arts and the others "The case of Gazi University". Universal Journal of Educational Research, 7(1), 198-205.

PAU-IPCC. (2018). Sports Management Department Course Catalogue. Information Package and Course Catalogue of Pamukkale University. Retrieved from https://ebs.pau.edu.tr/BilgiGoster/Program.aspx?lng=2\&dzy=3\&br=8273\&bl=8277\&pr=579\&dm=1\&ps=0

Pearce, C. L., \& Manz, C. C. (2005). The new silver bullets of leadership: The importance of self-and shared leadership in knowledge work. Organizational Dynamics, 34(2), 130-140. https://doi.org/10.1016/j.orgdyn.2005.03.003

Politis, J. D. (2003). QFD: The role of various leadership styles. The Leadership \& Organization Development Journal, 24(4), 181-92. https://doi.org/10.1108/01437730310478057

Politis, J. D. (2006). Self-leadership behavioural-focused strategies and team performance: The mediating influence of job satisfaction. Leadership \& Organization Development Journal, 27(3), 203-216. https://doi.org/10.1108/01437730610657721

Riggio, R. E. (2008). Leadership development: The current state and future expectations. Consulting Psychology Journal: Practice and Research, 60(4), 383-392. https://doi.org/10.1037/1065-9293.60.4.383

Robbins, S. P. (2003). Organisational Behaviour (10th ed.). Prentice-Hall Inc., Upper Saddle River, NJ.

Şahin, F. (2015). The convergent, discriminant, and concurrent validity of scores on the abbreviated self-leadership questionnaire. The Journal of Human and Work, 2(2), 91-104.

Semerci, N. (2010). The relationships between self-leadership and critical thinking. African Journal of Business Management, 4(8), 1639-1643.

Sesen, H., Tabak, A., \& Arl1, O. (2017). Consequences of self-leadership: A study on primary school teachers. Educational Sciences: Theory \& Practice, 17, 945-968. https://doi.org/10.12738/estp.2017.3.0520

Stech, E. (2008). Leadership education, training, and development: What should we be doing and what can we be doing? Journal of Leadership Education, 7(1), 43-46. https://doi.org/10.12806/V7/I1/C1

Stewart, G. L., \& Manz, C. C. (1995). Leadership for self-managing work teams: a typology and integrative model. Human Relations, 48(7), 747-770. https://doi.org/10.1177/001872679504800702

Stewart, G. L., Courtright, S. H., \& Manz, C. C. (2011). Self-leadership: A multilevel review. Journal of Management, 37(1), 185-222. https://doi.org/10.1177/0149206310383911

Sungur, N. (1997). Yaratıcı Düşünce. Ankara: Evrim Yayınları.

Tabak, A., Sığrı, Ü., \& Türköz, T. (2013). Öz liderlik ölçeğinin Türkçeye uyarlanması çalışması. Bilig, 67, 213-246. https://doi.org/10.12995/bilig.2013.6710

Tekin, A., \& Zorba, E. (2001). Spor ve rekreasyon organizasyonlarında etkili liderlik. Atatürk Üniversitesi Beden Eğitimi ve Spor Bilimleri Dergisi, 1(2), 28-36.

Türköz, T., Mutlu, T. O., Tabak, A. \& Erdoğan, M. (2013). Examining the levels of self-leadership perceptions of university student-athletes in terms of saciodemographic characteristics. Physical Culture and Sport Studies and Research, Volume LVIII, 43-52. https://doi.org/10.2478/pcssr-2013-0011

Virakul, B., \& McLean, G. (2012). Leadership development in selected leading Thai companies. Journal of Leadership Studies, 6(1), 6-22. https://doi.org/10.1002/j1s.21224

Vohra, N., Rathi, N., \& Bhatnagar, D. (2015). Developing leadership skills among EMBA students: Innovations in design. The Journal for Decision Makers, 40(1), 15-27. https://doi.org/10.1177/0256090915573612 
Zyl, E. S. (2012). Self-leadership: The way forward for African managers? African Journal of Business Management, 6(1), 118-128.

\section{Copyrights}

Copyright for this article is retained by the author(s), with first publication rights granted to the journal.

This is an open-access article distributed under the terms and conditions of the Creative Commons Attribution license (http://creativecommons.org/licenses/by/4.0/). 